\title{
Treeline advances and associated shifts in the ground vegetation alter fine root dynamics and mycelia production in the South and Polar Urals
}

\author{
Emily F. Solly ${ }^{1} \cdot$ Ika Djukic $^{1} \cdot$ Pavel A. Moiseev ${ }^{2} \cdot$ Nelly I. Andreyashkina $^{2} \cdot$ Nadezhda M. Devi $^{2} \cdot$ Hans Göransson $^{3} \cdot$ \\ Valeriy S. Mazepa ${ }^{2} \cdot$ Stepan G. Shiyatov $^{2} \cdot$ Marina R. Trubina $^{2} \cdot$ Fritz H. Schweingruber $^{1} \cdot$ Martin Wilmking $^{4}$. \\ Frank Hagedorn ${ }^{1}$
}

Received: 27 December 2015 / Accepted: 19 November 2016 / Published online: 30 November 2016

(C) Springer-Verlag Berlin Heidelberg 2016

\begin{abstract}
Climate warming is shifting the elevational boundary between forests and tundra upwards, but the related belowground responses are poorly understood. In the pristine South and Polar Urals with shifts of the treeline ecotone documented by historical photographs, we investigated fine root dynamics and production of extramatrical mycorrhizal mycelia (EMM) along four elevational transects reaching from the closed forest to the treeless tundra. In addition, we analysed elevational differences in climate and vegetation structure, and excavated trees to estimate related changes in the partitioning between below- and aboveground biomass. Fine root biomass of trees $(<2 \mathrm{~mm})$ increased by 13-79\% with elevation, paralleled by a $35-72 \%$ increase in ground vegetation fine roots from the closed forest to the tundra. During the first year of decomposition, mass loss of fine root litter from different vegetation types was greater at lower elevations in the forest-tundra ecotone. The ratio between fine roots of trees and stem
\end{abstract}

Communicated by Russell K. Monson.

Electronic supplementary material The online version of this article (doi:10.1007/s00442-016-3785-0) contains supplementary material, which is available to authorized users.

Emily F. Solly

emily.solly@wsl.ch

1 Swiss Federal Institute for Forest, Snow and Landscape Research WSL, Zürcherstrasse 111, Birmensdorf, 8903, Zurich, Switzerland

2 Institute of Plant and Animal Ecology, Yekaterinburg, Russia

3 Institute of Forest Ecology, University of Natural Resources and Life Sciences, Vienna, Austria

4 Institute for Botany and Landscape Ecology, University Greifswald, Greifswald, Germany biomass largely increased with elevation in both regions, but these increases were not accompanied by a distinct production of EMM. Production of EMM, however, increased with the presence of ectomycorrhizal trees at the transition from the tundra to the forest. Our results imply that the recorded upward expansion of forest into former tundra in the Ural Mountains by $4-8 \mathrm{~m}$ per decade is decreasing the partitioning of plant biomass to fine roots. They further suggest that climate-driven forest advances will alter EMM production rates with potential feedbacks on soil carbon and nutrient cycling in these ecosystems.

Keywords Treeline shifts · Ural Mountains · Fine roots · Extramatrical mycorrhizal mycelia $\cdot$ Global change

\section{Introduction}

During the last century, global temperatures have risen, with the most rapid increases occurring in high elevation and high latitude ecosystems (Arctic Climate Impact Assessment 2005; IPCC 2013). Global warming has substantial impacts on vegetation and alters the spatial distribution of ecosystems influencing carbon (C) turnover times (Gonzalez et al. 2010; Carvalhais et al. 2014). These effects are particularly marked in boundary ecosystems, with a steep transition between vegetation types over short distances (Sturm et al. 2001; Grace et al. 2002; Stow et al. 2004; Hartley et al. 2012; Parker et al. 2015). The upper treeline is globally one of the most evident boundary ecosystems, separating forest and tundra vegetation dominated by shrubs and herbaceous plants (grasses, sedges and herbs) (Körner 2012). At the treeline ecotone, low growing season temperatures impose a limit to tree growth and reproduction (Körner 2003). Advances of woody vegetation 
towards higher elevations and latitudes have been recorded in several regions worldwide over the last century in North America, Scandinavia, Siberia, and the Ural Mountains (Kullman 2002; Moiseev and Shiyatov 2003; Esper and Schweingruber 2004; Lloyd 2005). Upward shifts of forests have been mainly associated with continuous rises of regional temperatures and ameliorated winter conditions (Harsch et al. 2009; Holtmeier 2009; Hagedorn et al. 2014). Within a few metres in elevation, there are abrupt shifts in vegetation composition and biomass, microbial communities, soil development, albedo, as well as $\mathrm{C}$ and nutrient dynamics (Holtmeier 2009; Kammer et al. 2009; Körner 2012; Grafius and Malanson 2015). As a result, forest advances into the tundra will likely alter the amount of $\mathrm{C}$ stored in these ecosystems through changes in plant biomass partitioning and decomposition rates.

Fine roots sustain plant water and nutrient acquisition and mediate a number of processes in soil $\mathrm{C}$ cycling, such as inputs of $\mathrm{C}$ to soil organic matter through their decomposition, exudation, mycorrhizal associations, and influence on the microbial activity (Grayston et al. 1997; Zhu and Miller 2003; Solly et al. 2014). Nevertheless, most studies at the upper limit of trees focus on quantifying aboveground vegetation structure and composition to understand the mechanisms underlying the position and formation of the treeline ecotone. In contrast to the marked decrease in tree height and aboveground biomass towards the upper limit of trees, the few belowground studies in mountain forests have observed particularly high fine root biomass of trees at higher elevations (Leuschner et al. 2007; Hertel and Schöling 2011a). The reasons are still uncertain, but results from studies in Central Europe and tropical mountain forests suggest that a greater amount of fine roots at higher elevations may be, at least in relative terms, related to an adjustment to reduced nitrogen $(\mathrm{N})$ availability (Hertel and Schöling 2011b; Moser et al. 2011). Nitrogen-driven responses may be particularly marked in cold regions characterized by N-poor soils (Chapin et al. 1995; Kammer et al. 2009; Melillo et al. 2011; Bai et al. 2013; Dawes et al. 2016).

Across the forest-tundra ecotone, ground vegetation also varies and climate change may affect the species composition as well as productivity of the ground vegetation either directly by warmer temperatures (Anadon-Rosell et al. 2014) or indirectly by the protection from harsh environmental conditions by trees (Trubina 2006; Kirdyanov et al. 2012). In northern latitudes and high altitudes, there has been an increase in shrub cover due to climate warming, with potential impacts on snow accumulation, aboveground biomass buildup and $\mathrm{C}$ inputs into soils (Olthof and Pouliot 2010; Myers-Smith et al. 2011). Shifts in plant functional types associated with treeline advances are likely to alter fine root biomass and turnover, but our current quantitative knowledge is very limited (Sloan et al. 2013; Iversen et al. 2015).

Decomposition of plant litter drives biogeochemical cycling in terrestrial ecosystems (Hobbie 1992). The process of litter decomposition is mainly controlled by environmental conditions, litter quality, and soil organisms (Berg 1984; Handa et al. 2014; Solly et al. 2014, 2015). Observational investigations indicate that at higher elevations decomposition rates are slower mainly due to lower soil temperatures (Chen et al. 2008). However, the effects of climatic factors may be modified by different plant species across the forest-tundra ecotone, altering the quality of litter inputs into soils (Handa et al. 2008). In the Tibetan Plateau, for instance, Liu et al. (2016) showed that interspecific effects on the decomposition were larger than between an alpine meadow and a coniferous forest at lower elevations, suggesting that species composition has a dominant influence on decomposition. It is likely that changes in vegetation cover due to tree establishment in the tundra will strongly impact decomposition rates at the treeline ecotone by both changes in microclimatic conditions and litter quality.

Mycorrhizal fungi play a critical role in plant nutrition and $\mathrm{C}$ balance, generally improving the foraging ability of plants through a mutualistic relationship in exchange for carbohydrates (Smith and Read 1996). The production of extramatrical mycorrhizal mycelia (EMM) is responsive to environmental conditions, such as nutrient availability or temperature, as it is a dynamic component of mycorrhizal symbiosis (Clemmensen et al. 2006; Wallander 2006; Leppälammi-Kujansuu et al. 2013) and provides efficient routes of $\mathrm{C}$ and nutrient flows in the plant and soil system (Simard et al. 2003). The production of EMM commonly increases with a greater photosynthetic capacity of host plants (Högberg et al. 2001; Hobbie 2006). At a subarctic treeline in Northern Scandinavia, there was a lower hyphal in-growth in tundra heath than at the edge of birch forest, which was related to an increasing abundance of host trees (Parker et al. 2015). Also, the richness of ectomycorrhizal fungi species declined with elevation in two treeline ecotones in the Canadian Rockies (Kernaghan and Harper 2001) and along elevational transects in Iran (Bahram et al. 2012). In addition to changes in plant biomass and vegetation composition, global warming is likely to influence the production of EMM by accelerating $\mathrm{N}$ mineralization (Dawes et al. 2016), for instance a greater $\mathrm{N}$ availability may stimulate the production of EMM in $\mathrm{N}$-poor ecosystems in cold regions (Clemmensen et al. 2006).

In pristine regions of the Ural Mountains, comparisons of recent and historical photos indicate that forests in these regions have advanced upwards by $4-8 \mathrm{~m}$ per decade, largely altering the position of the forest-tundra ecotone (Fig. 1, Kammer et al. 2009; Hagedorn et al. 2014). In this 
Fig. 1 Forests are expanding to higher elevations in the Ural Mountains, as documented in the comparison between historical and recent photographs (example of the Mali Iremel, South Urals, in 1929 and 2012) (see also Kammer et al. 2009; Hagedorn et al. 2014). The figure is available in colour in the online version of the journal
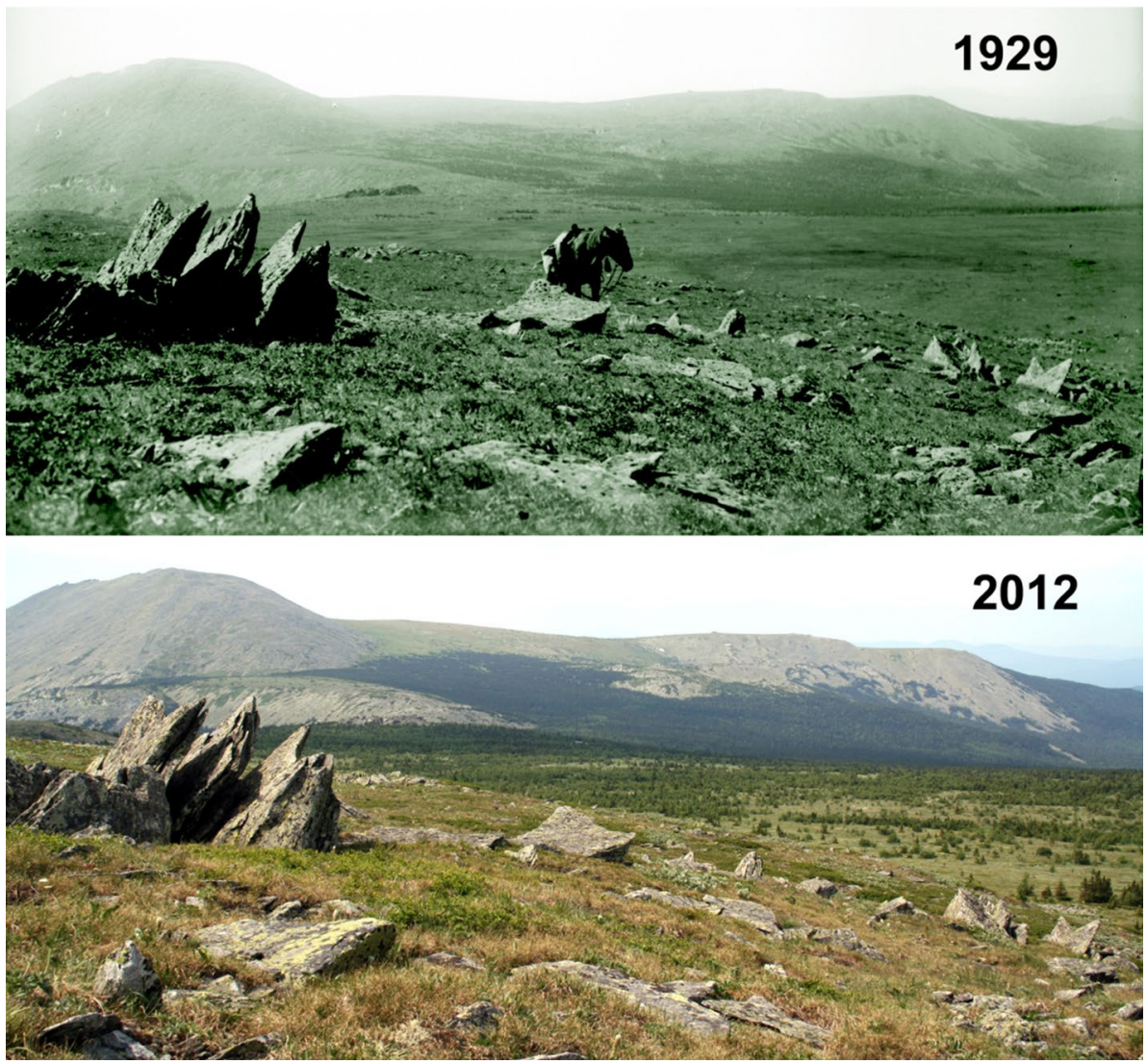

study, we investigated changes in fine root biomass, fine root litter decomposition, and the production of EMM along four elevational transects reaching from the tundra to the closed forest in the South and Polar Urals. Knowledge from field studies about changes in belowground plant biomass with elevation is often confined to fine roots $<2 \mathrm{~mm}$, especially for trees, due to the destructive nature of major sampling efforts in the soil. Here in our study, we also assessed the biomass of entire root systems to determine the effect of changing climatic factors with elevation for the partitioning between above- and belowground biomass. Our hypotheses are that (1) fine root biomass increases with elevation paralleled by a decrease of tree aboveground biomass and tree height, (2) root litter decomposition is slower at higher elevations mainly due to a less favourable microclimate than at low elevations, and (3) the production of EMM increases from the tundra to the closed forest as a result of greater abundance and faster growth of ectomycorrhizal trees.

\section{Materials and methods}

\section{Study sites}

We conducted our study in two different regions of the Ural Mountain range: the South and the Polar Urals
(Fig. 1). The two regions are distinct by their soil parent material, climate, and vegetation composition. In the South Urals, the soil parent material is quartzite, while in the Polar Urals the dominant parent material is ultramafic rock. The mean annual precipitation ranges between 600 and $900 \mathrm{~mm}$ in the South Urals, and 450 and $820 \mathrm{~mm}$ in the Polar Urals. Both summer and winter air temperatures are higher in the South Urals than in the Polar Urals (Table 1). The maximal snow depth is $80-150 \mathrm{~cm}$ in the South Urals and $150-250 \mathrm{~cm}$ in the Polar Urals. Siberian spruce (Picea obovata Ledeb.) is the dominant tree species in the South Urals; Siberian larch (Larix sibirica Ledeb.) is the main tree species found in the Polar Urals. In the South Urals, the tundra is dominated by dwarf shrubs (Vaccinium uliginosum L., Vaccinium vitis-idaea L.), grasses, and sedges (Carex vaginata Tausch, Festuca igoschiniae Tzvelev). Below $1330 \mathrm{~m}$ a.s.l., Picea obovata trees alternate with open areas where productive herbs (Polygonum bistorta L., Polygonum alpinum All.) grow to a height of $1.5 \mathrm{~m}$. In the Polar Urals, the vegetation forming the tundra and dominating the open areas between groups of trees consists of different shrubs (Betula nana L., Salix phylicifolia L., Vaccinium uliginosum L.) and herbs (e.g. Polygonum bistorta L., Thalictrum alpinum L., Solidago lapponica With). More information about the study regions can be found in Table 1 and in Hagedorn et al. (2014). 
Table 1 Characteristics of the study areas in the Ural Mountains and elevational range of the four transects

\begin{tabular}{|c|c|c|}
\hline & South Urals & Polar Urals \\
\hline \multicolumn{3}{|l|}{ Geographical coordinates } \\
\hline $\mathrm{N}$ & $54^{\circ} 30^{\prime}-54^{\circ} 34^{\prime}$ & $66^{\circ} 47^{\prime}-66^{\circ} 51^{\prime}$ \\
\hline $\mathrm{E}$ & $58^{\circ} 49^{\prime}-58^{\circ} 54^{\prime}$ & $65^{\circ} 26^{\prime}-65^{\circ} 38^{\prime}$ \\
\hline Transects & Bolshoi Iremel (1291-1405) & Tschernaya North (200-320) \\
\hline (Elevational range, $\mathrm{m}$ a.s.1.) & Mali Iremel (1262-1400) & Tschernaya West (231-300) \\
\hline Geology & Quartzite, carbon-clay shale & Ultramafic rock \\
\hline Mean June air temperature, ${ }^{\circ} \mathrm{C}$ & +16 to +19 & +12 to +14 \\
\hline Mean January air temperature, ${ }^{\circ} \mathrm{C}$ & -15 to -17 & -21 to -24 \\
\hline Annual precipitation ${ }^{\mathrm{a}}, \mathrm{mm}$ & $600-900$ & $450-820$ \\
\hline Snow depth range, $\mathrm{cm}$ & $80-150$ & $150-250$ \\
\hline Dominant tree species ${ }^{b}$ & Po, Bp & Ls \\
\hline
\end{tabular}

a Measured next to meteorological stations with altitudes of 457 and $1102 \mathrm{~m}$ a.s.l. in the South Urals, and 16 and $890 \mathrm{~m}$ in the Polar Urals

b Po Picea obovata, Bp Betula pubescens ssp., Tortuosa. Ls Larix sibirica

\section{Sampling design}

We established two elevational transects across the treeline ecotone reaching from the tundra to the closed forest in each of the two regions, namely the "Bolshoi Iremel" (1291-1405 m a.s.l.) and the "Mali Iremel" (1262-1400 m a.s.l.) transects on the Iremel massif in the South Urals and the "Tchernaya North" (200-320 m a.s.l.) and "Tchernaya West" (231-300 $\mathrm{m}$ a.s.l.) transects on the Tchernaya massif in the Polar Urals. The two transects in each of the regions are approximately $5 \mathrm{~km}$ apart from each other. They are all characterized by gentle slopes $\left(<10^{\circ}\right)$. Soils are rather homogenous showing similar $\mathrm{pH}$ values and parent material from the forest to the tundra (Kammer et al. (2009); Hagedorn et al. (2014). Along the transects, we selected four elevation levels: 'tundra'(without trees, $0 \%$ tree crown cover), dominated by shrubs and herbaceous plants (grasses, sedges, and herbs), the 'tree species line' the uppermost clusters of trees with adjacent tundra (with trees $>2 \mathrm{~m}$; proportion of tree crown cover $<10 \%$ and distances between trees from 20 to $60 \mathrm{~m}$ ), the 'open forest' (proportion of tree crown cover $20-30 \%$ and distances between trees from 7 to $30 \mathrm{~m}$ ), and the 'closed forest' (proportion of tree crown cover of $38 \%$ or more and distances between trees from 7-10 m). The proportion of tree crown cover for all levels in the different transects is reported in Table 5S. At each elevation level, we randomly set up three plots of $20 \times 20 \mathrm{~m}$ spanning a horizontal distance of approximately $200 \mathrm{~m}$. In each of the plots (from the tree species line to the closed forest), we further randomly selected one subplot $(1 \times 1 \mathrm{~m})$ 'under a tree' representing the typical age class and height $(>2 \mathrm{~m})$ of the altitudinal level (Table 5S) and an adjacent subplot $(1 \times 1 \mathrm{~m})$ in the 'open land', a canopy free area with shrubs and herbaceous plants in between tree clusters (distance to trunk $2.5-6 \mathrm{~m}$ ). In the tundra dominated by shrubs and herbaceous plants, three plots in the open land were further set up resulting in a total of 48 plots and 84 subplots.

\section{Forest stand structure analysis and soil temperatures}

In each of the plots (area of $20 \times 20 \mathrm{~m}$ ), all trees and saplings taller than $0.2 \mathrm{~m}$ were counted. The basic morphometric parameters such as tree height, diameter at base and breast height, and stem density (number of trees per hectare) were recorded. The age structure of the trees in all plots was determined by dendrochronological methods as follows. From all trees with diameters exceeding $3-5 \mathrm{~cm}$ at their base, we took tree cores at heights from 0 to $30 \mathrm{~cm}$, and from every second tree taller than $0.2 \mathrm{~m}$ but less than $3-5 \mathrm{~cm}$ in diameter, we sampled stem disks at the root collar. All cores were mounted on wooden strips. After enhancing ring boundary contrasts with white powder, samples with narrow annual rings were measured on the linear table LINTAB-V (F. Rinn S.A., Heidelberg) to a precision of $0.01 \mathrm{~mm}$ and were cross-dated using the computer program TSAP-3.0 (Rinn 1998) and Cofecha (Holmes 1995). Samples with wide rings were visually crossdated, paying special attention to frost and light rings. The dates of tree germination were estimated by correcting for the number of years required to grow to the height of sampling and for the number of years to the pith when the core missed the inner ring. For cores hitting the pith, the distance to the centre of the tree was estimated by fitting a circular template to the innermost curved ring (Braeker 1981). The number of years it took for a stem to grow to the core height was determined from a regression of tree age with height established for all seedlings and saplings at each study site (Hagedorn et al. 2014). At every elevation level of each transect, we also estimated the proportion of 
tree crown cover of trees, as well as the cover abundance of shrubs and herbaceous plants directly on the plot area $(20 \times 20 \mathrm{~m})$ using $1 \times 1 \mathrm{~m}$ frames $(n=32)$. These values were comparable to the cover values obtained by determining the average of the area covered by the different growth forms in every cell of a grid (cell grid $20 \times 20 \mathrm{~mm}$ ), which was overlaid over orthogonal photographs of each subplot. The cover of larger stones at the surface was estimated in the same way. Soil temperature was measured continuously every hour with ground surface temperature dataloggers (MaximiButton, DS1921G, Sunnyvale, CA, USA) placed at $10 \mathrm{~cm}$ depth in both the open land and under the tree canopy along the elevational transects of the Mali Iremel, Tchernaya Nord, and Tchernaya West transects (Table 6S). We calculated the soil temperature during the growing season based on the $3.2{ }^{\circ} \mathrm{C}$ soil temperature threshold adopted by Körner and Paulsen (2004) to define the beginning and the end of the growing season (Table 6S, data used in the path analysis, see "Calculations and statistics" section). Snow depths were measured in March. We assume the climatic conditions to be similar at the Mali Iremel and the Bolschoi Iremel, due to the spatial proximity and almost identical altitudes of these transects.

\section{Soil sampling, root collection, and analysis}

Soil samples were collected in July and August 2013. In each subplot we removed the litter (L) and a very shallow fermentation (F) horizon and collected soil samples from 0 to $5 \mathrm{~cm}$ (F- and H-layer), 5 to $10 \mathrm{~cm}$ (Ah horizon) and 10 to $20 \mathrm{~cm}$ ( $\mathrm{AB}$ horizon) depth by using a soil corer with an inner diameter of 8 or $10 \mathrm{~cm}$ in the South Urals. In the stone-rich Polar Urals, we excavated a quantitative soil pit of an area of approximately $20 \times 20 \mathrm{~cm}$ and collected the total soil material from the same depth layers. The exact volume for each depth layer was determined by measuring the dimension with a ruler and by filling the hole with a known volume of sand. Root biomass and gravel/stones were carefully manually picked out from the soil samples and soils were sieved to $2 \mathrm{~mm}$. We removed the mineralsoil particles attached to the roots by carefully washing the roots with deionized water in a $63 \mu \mathrm{m}$ sieve. Samples were dried at $40{ }^{\circ} \mathrm{C}$ to constant weight in a force air oven, then separated into different diameter classes (1-2 mm-conductive roots, and $<1 \mathrm{~mm}$-including mycorrhizal root tips) and weighed. Living (biomass) and dead fine roots (necromass) were distinguished under a stereo microscope based on colour, cohesion of cortex, and viscosity (Persson 1980). For the fine roots with a diameter $<1 \mathrm{~mm}$, a homogenous subsample (1/4 of the sample) was subjected to a detailed analysis under a stereo microscope and the total amount of dead root material extrapolated by regression analysis. The visual sorting of fine roots into different species or growth forms is challenging in treeline ecotones (e.g. shrub fine roots and rhizomes are not easily distinguished from fine roots of trees due to their woody anatomy), especially for small root fragments $(<10 \mathrm{~mm})$, and may result in a major source of error. Therefore, to determine which plant species and growth forms contribute to the root biomass, we anatomically investigated randomly selected fine roots with different diameters at two altitudinal levels, the tree species line and the closed forest, along the Mali Iremel and the Tchernaya Nord transects (9-12 thin sections per subplot per root diameter type at $0-5$ and $5-10 \mathrm{~cm}$ soil depth). The thin sections (approximately, 15-20 $\mu \mathrm{m}$ ) were prepared using a laboratory microtome (Gärtner and Schweingruber 2013), covered with glycerol and a cover glass, and analysed with a BX41 Olympus microscope. By observing the anatomical characteristics of fine root thin sections, it was possible to identify to which plant species or growth form a root belonged to (Schweingruber 1978; Cutler et al. 1987) and to create a morphology root reference collection based on root anatomy checks. Fine root biomass of trees and of the ground vegetation (shrubs, grasses, sedges, and herbs) were then separated and weighed.

\section{Above- and belowground plant biomass}

The tree above- and belowground plant biomass was determined by measuring the biomass of selected trees representing different heights and diameters at different elevational levels. We carefully excavated different compartments including the coarse root system (threshold $<1 \mathrm{~cm}$ ), the stems and the needles of 39 trees at the tree species line and 18 trees from the open forest to the closed forest along the transects in the South Urals. In the Polar Urals, we selected 28 trees from the tree species line to the closed forest of the elevational transects. The dry masses of the biomass fractions were used to fit allometric functions between the biomass of the various compartments and tree diameters as well as tree heights. These functions were then used to estimate the tree biomass of each of the plots (area of $20 \times 20 \mathrm{~m}$ ) along the elevational transects based on specific tree diameters and heights. The aboveground biomass of shrubs (leaves, stems and twigs) and herbaceous plants (stems) was collected on 24 subplots from the tundra to the closed forest along the elevational transects of the South Urals and 16 subplots in the elevational transects of the Polar Urals, dried at $70{ }^{\circ} \mathrm{C}$, and weighed. The subplots had a size of $0.25 \times 0.25 \mathrm{~m}$ if dominated by herbaceous plants, or a size of $0.5 \times 0.5 \mathrm{~m}$ if dominated by shrubs.

\section{Fine root decomposition}

Mass loss of fine root litter was studied during a 1 year litterbag experiment. Living fine roots of different plant 
growth forms (Polygonum spp., Picea obovata in the South Urals, and Larix sibirica, a mixture of shrubs and a mixture of herbs in the Polar Urals) were collected at the tree species line and in the closed forest of the Mali Iremel (South Urals) and Tchernaya North (Polar Urals) transects. The biomass of fine roots was weighed after drying the root samples at $40{ }^{\circ} \mathrm{C}$. One gram of belowground litter was added to $1 \mathrm{~mm}$ mesh size enclosure $(10 \mathrm{~cm} \times 10 \mathrm{~cm}$, propylene). Ten litterbags of fine roots of each of the different plant growth forms were placed vertically into the topsoil at $0-10 \mathrm{~cm}$ depth at the beginning of the growing season and kept in the soil for 1 year. The litterbags were distributed in one plot at the tree species line and in the closed forest, in the Mali Iremel and the Tchernaya North transects. After collection, the decomposed root litter was dried at $40{ }^{\circ} \mathrm{C}$ and we calculated the fine root mass loss in $\%$.

\section{Extramatrical mycorrhizal mycelia production}

The extramatrical mycorrhizal mycelia (EMM) production was measured with ingrowth mesh bags (Wallander et al. 2001). In summer 2013, EMM mesh bags (with a mesh size of $0.50 \mu \mathrm{m}$ and filled with organic matter free 0.06 to $0.25 \mathrm{~mm}$ quarz sand) were placed at $0-5 \mathrm{~cm}$ soil depth in both the open land and under the tree canopy and were incubated for 1 year along all of the four studied transects (4 replicates per subplot). After the collection, the bags were kept at $+4{ }^{\circ} \mathrm{C}$, brought to the laboratory, and stored at $-20^{\circ}$ until analysis. When adopting the ingrowth bag approach, some artefacts need to be considered, such as microclimate alterations and differences in the substrate quality between quartz sand and native soil (Wallander 2006). Nevertheless, this approach represents a relative measure and enables the comparison of mycelia production among ecosystems. Each mycorrhizal ingrowth bag was then analysed for ergosterol (Nylund and Wallander 1992). Lipids were extracted from a subsample of $5 \mathrm{~g}$ of sand with $5 \mathrm{ml} 10 \% \mathrm{KOH}-$ methanol solution and $2 \mathrm{ml}$ cyclohexane, which was vortexed for $1 \mathrm{~min}$ and centrifuged for $5 \mathrm{~min}$ at $1000 \times \mathrm{g}$ (phase separation was repeated after the addition of $2 \mathrm{ml}$ cyclohexane). The chromatographic system we adopted was a C 18 reverse-phase column (LiChrospher 100 (125-44 mm), Lichrocart RP-18 (5 $\mu \mathrm{m}$ ), Merck). Extracts were eluted with methanol at a flow rate of $1 \mathrm{ml} \mathrm{min}{ }^{-1}$ and detected using a UV detector at $282 \mathrm{~nm}$.

\section{Chemical analysis of roots and soils}

After soil sampling, soils were kept cool in a soil pit $\left(<10{ }^{\circ} \mathrm{C}\right)$. The samples were transported in cooling boxes to the laboratory where the inorganic $\mathrm{N}$ concentrations were extracted with $1 \mathrm{M} \mathrm{KCl}$ in a 1:5 ratio for $1 \mathrm{~h}(1: 10$ for soil samples collected at $0-5 \mathrm{~cm}$ depth). In the extracts,
$\mathrm{NH}_{4}^{+}$was measured by automatic flow injection analysis (PE FIAS-300, Perkin-Elmer, Norwalk, CT, USA) and $\mathrm{NO}_{3}{ }^{-}$concentrations by ion chromatography (DX-120, Dionex, Sunnyvale, CA, USA). For C and N analysis in the soil, subsamples were dried to $40{ }^{\circ} \mathrm{C}$ and ground with a ball mill. In soils and total fine root samples (representing the combined fine root biomass of trees and of shrubs and herbaceous plants), $\mathrm{C}$ and $\mathrm{N}$ concentrations and $\delta^{15} \mathrm{~N}$ values were measured using a $\mathrm{CN}$-analyser (Euro EA Hekatech $\mathrm{GmbH}$ ) interfaced with a continuous flow isotope ratio mass spectrometer (Delta-V Advanced IRMS, Thermo $\mathrm{GmbH}$, Germany).

\section{Calculations and statistics}

Root biomass, soil $\mathrm{C}$ stocks, and the soil-extractable inorganic $\mathrm{N}\left(\mathrm{NH}_{4}{ }^{+}+\mathrm{NO}_{3}{ }^{-}\right)$pool size were converted using soil bulk density measurements and corrected on an areal basis by considering the amount of stones in each plot measured by the stone volume in quantitative soil pits (Tamminen and Starr 1994) as well as by the areal cover of larger stones (see above). The amount of total living fine root biomass (all plant growth forms combined) at the ecosystem level was also calculated by considering the cover of tree crown, which varies along the transects. We used linear mixed effect models fitted with restricted maximum likelihood (REML) to investigate the effects of regions (South and Polar Urals) and elevation on fine root biomass of trees and of the ground vegetation. The effects of regions, elevation, and vegetation (under tree and open land) on the production of EMM, soil C stocks, soil C/N ratio, extractable inorganic $\mathrm{N}$ pool size, and chemical properties of fine root biomass of all plant growth forms combined ( $\mathrm{C}$ and $\mathrm{N}$ concentrations, and $\delta^{15} \mathrm{~N}$ values) were also assessed with linear mixed effect models. To account for the design of the field experiment, we included the transect, the elevational level, and the plot as random effects. We tested the significance of all of the fixed effect variables and their interactions with conditional $F$ tests. Using the diagnostic plot function in $\mathrm{R}$, we checked the model assumptions (Crawley 2012). The influence of tree stand properties across the elevational transects on tree root biomass was assessed by calculating Pearson's correlation values and assessing their significance in $\mathrm{R}$ using the chart. Correlation function was implemented in the Performance Analytics package. Path analysis was used to explore the potential causal relationships between climate (growing period soil T), vegetation structure, the total root biomass, and soil organic $\mathrm{C}$ stocks. To parameterize the vegetation structure in the path analyses, we selected changes of the cover of shrubs and trees in all plots. Path analysis was performed using the Lavaan package in R. The adequacy of the hypothesized structural relationships was verified using $\chi^{2}$ test and AIC. All 
Table 2 (a) Results of linear regression between elevation and mean soil temperatures, aboveground tree stand parameters, soil C stocks, extractable soil inorganic nitrogen pools, and soil $\mathrm{C} / \mathrm{N}$ ratios in the South Urals and Polar Urals. (b) Output of the linear mixed effects models to study the effect of region and elevation on fine root biomass of trees as well as of the ground vegetation (shrubs and herbaceous plants, GV)

\begin{tabular}{|c|c|c|c|c|c|c|c|c|c|c|c|c|c|c|c|}
\hline \multirow[t]{3}{*}{ (a) } & & & & \multicolumn{4}{|c|}{ Elevation (m a.s.1.) South Urals } & \multicolumn{4}{|c|}{ Elevation (m a.s.1.) Polar Urals } & \multirow{2}{*}{\multicolumn{4}{|c|}{$\begin{array}{l}\text { Tree fine roots }<2 \mathrm{~mm} \\
\left(\mathrm{~g} \mathrm{~m}^{-2}\right) \\
\text { Pearson's correlation }\end{array}$}} \\
\hline & & & & \multirow[t]{2}{*}{$\overline{R^{2}}$} & \multirow{2}{*}{$\begin{array}{l}\text { Direction } \\
\text { of slope }\end{array}$} & \multirow{2}{*}{\multicolumn{2}{|c|}{$P$}} & \multirow{2}{*}{\multicolumn{2}{|c|}{$R^{2}$}} & \multirow{2}{*}{$\begin{array}{l}\text { Direction of } \\
\text { slope }\end{array}$} & \multirow[t]{2}{*}{$P$} & & & & \\
\hline & & & & & & & & & & & & \multicolumn{2}{|c|}{ South Urals } & \multicolumn{2}{|c|}{ Polar Urals } \\
\hline & \multicolumn{3}{|c|}{ Soil annual mean temperature $\left({ }^{\circ} \mathrm{C}\right)$} & 0.98 & $\searrow$ & \multicolumn{2}{|c|}{$<0.01$} & \multicolumn{2}{|c|}{0.88} & $\searrow$ & $<0.01$ & & & & \\
\hline & \multicolumn{3}{|c|}{$\begin{array}{l}\text { Soil growing season mean temperature } \\
\left({ }^{\circ} \mathrm{C}\right)\end{array}$} & 0.75 & $\searrow$ & \multicolumn{2}{|c|}{$<0.01$} & \multicolumn{2}{|c|}{0.78} & $\searrow$ & $<0.01$ & & & & \\
\hline & \multicolumn{3}{|l|}{ Mean tree height $(\mathrm{cm})$} & 0.89 & $\searrow$ & \multicolumn{2}{|c|}{$<0.01$} & \multicolumn{2}{|c|}{0.72} & $\searrow$ & $<0.05$ & \multicolumn{2}{|l|}{-0.59} & \multicolumn{2}{|c|}{-0.64} \\
\hline & \multicolumn{3}{|l|}{ Mean tree age (years) } & 0.08 & $\searrow$ & \multicolumn{2}{|c|}{ n.s. } & \multicolumn{2}{|c|}{0.512} & $\searrow$ & $<0.05$ & \multicolumn{2}{|l|}{-0.57} & \multicolumn{2}{|c|}{-0.75} \\
\hline & Stem biomass of the sta & Is (t ha & & 0.88 & $\searrow$ & & & 0.8 & & $\searrow$ & $<0.01$ & -0.51 & & $-\mathbf{0}$. & .55 \\
\hline & Proportion of tree crow & over $(c$ & & 0.96 & $\searrow$ & & & 0.6 & & $\searrow$ & $<0.05$ & -0.66 & & $-\mathbf{0}$ & 38 \\
\hline & $\begin{array}{l}\text { Extractable } \mathrm{N} \mathrm{mg} \mathrm{NH}{ }_{4}^{+} \\
0.2 \mathrm{~m}^{-1} \mathrm{~m}^{-2}\end{array}$ & $\mathrm{JO}_{3}^{-} \mathrm{N}$ & & 0.28 & $\searrow$ & & & 0.4 & & $\searrow$ & $<0.01$ & -0.48 & & $-\mathbf{0}$ & 36 \\
\hline & Soil organic $\mathrm{C}$ stock $(\mathrm{k}$ & $\left(m^{-2}\right)$ & & 0.01 & None & n.s. & & 0.1 & & None & n.s & 0.34 & & 0.2 & 27 \\
\hline & Soil C/N ratio & & & 0.29 & None & n.s. & & 0.0 & & None & n.s. & 0.33 & & $\mathbf{0 .}$ & 44 \\
\hline (b) & Fixed effect & Tree & e root & $1 \mathrm{~mm}(\mathrm{~g}$ & & Tree & le ro & ots & $-2 \mathrm{~mm}$ & $\left(\mathrm{~g} \mathrm{~m}^{-2}\right)$ & $\begin{array}{l}\text { Total tre } \\
\left(\mathrm{g} \mathrm{m}^{-2}\right)\end{array}$ & e fine 1 & ots $<2$ & $2 \mathrm{~mm}$ & \\
\hline & & Dfn & Dfd & $F$ & $P$ & Dfn & Df & & $F$ & $P$ & Dfn & Dfd & $F$ & & $P$ \\
\hline & Region & 1 & 2 & 48.733 & 0.182 & 1 & 2 & & 4.646 & 0.164 & 1 & 2 & 10.5 & & 0.083 \\
\hline & Elevation & 1 & 14 & 5.598 & $\mathbf{0 . 0 3 3}$ & 1 & 14 & & 0.001 & 0.988 & 1 & 18 & 7.43 & & 0.014 \\
\hline & Region $\times$ elevation & 1 & 14 & 0.121 & 0.733 & 1 & 14 & & 4.837 & 0.045 & 1 & 18 & 1.07 & & 0.314 \\
\hline & Fixed effect & $\mathrm{GV} \mathrm{fi}$ & roots & $\mathrm{mm}(\mathrm{g}$ & & GV & e ro & ots 1 & $-2 \mathrm{~mm}$ & $\left(\mathrm{~g} \mathrm{~m}^{-2}\right)$ & GV fin & e roots & $2 \mathrm{~mm}$ & $(\mathrm{~g} \mathrm{n}$ & $\mathrm{n}^{-2}$ ) \\
\hline & & Dfn & Dfd & $F$ & $P$ & Dfn & $\mathrm{D}$ & & $F$ & $P$ & Dfn & Dfd & $F$ & & $P$ \\
\hline & Region & 1 & 2 & 5.364 & 0.147 & 1 & 2 & & 0.265 & 0.909 & 1 & 2 & 2.32 & & 0.266 \\
\hline & Elevation & 1 & 28 & 13.423 & 0.001 & 1 & 26 & & 2.798 & 0.107 & 1 & 27 & 9.51 & & 0.005 \\
\hline & Region $\times$ elevation & 1 & 28 & 0.901 & 0.351 & 1 & 26 & & 0.425 & 0.519 & 1 & 27 & 1.93 & & 0.175 \\
\hline
\end{tabular}

Pearson's correlation analysis between aboveground stand parameters, soil $\mathrm{C}$ stocks, extractable soil inorganic nitrogen stocks, and soil $\mathrm{C} / \mathrm{N}$ ratio with fine root biomass of trees

Numbers in bold represent significant effects $(P<0.05)$

variables were standardized to $(0,1)$. Statistical analyses were conducted with R (version 3.1.2, R Core Team 2014). Prior to analysis, we transformed data if necessary to meet assumptions of normality. The chosen $p$ value for detecting statistical differences was $P<0.05$.

\section{Results}

\section{Forest stand properties and site characteristics}

Along all four elevational transects, there was a significant linear decrease of mean annual temperatures of soils at $10 \mathrm{~cm}$ depth as well as mean growing season temperatures with elevation (Table $2 \mathrm{a}$, Table $6 \mathrm{~S}$ ). In parallel, the number of living trees per hectare showed a threefold decrease in the South Urals and a sevenfold decrease in the Polar Urals. The height and age of trees also decreased significantly (Table 2a, Table 5S). The soil-extractable inorganic $\mathrm{N}$ pool showed a marked decrease with elevation in both regions (Table 1S). It was more than ten times smaller in the Polar Urals than in the South Urals. In the South Urals, the soil organic $\mathrm{C}$ stocks of the main rooting zone down to $20 \mathrm{~cm}$ depth did not show a significant change with elevation, while in the Polar Urals they decreased from $3.0 \pm 0.3$ to $2.0 \pm 0.3 \mathrm{~kg} \mathrm{C} \mathrm{m}^{-2}$ in the open land subplots, and from $4.0 \pm 0.1$ to $0.9 \pm 0.1 \mathrm{~kg} \mathrm{C} \mathrm{m}^{-2}$ in subplots under trees (mean $\pm \mathrm{SE}, n=6$ ) (Table $1 \mathrm{~S}$ ). 
Fine root biomass, $\mathrm{C} N$ concentrations, and root isotopic composition

Fine root biomass of trees was only present in the subplots under trees and not in the subplots of the open land, and it was greater in the South Urals than in the Polar Urals although this difference was overall not significant (Table 2b). Along all four elevational transects in the forest-tundra ecotones of the Ural Mountains, fine root biomass of trees was higher at the tree species line than in the closed forest (Fig. 2, $P_{\text {Elevation }}<0.033$ for the $<1 \mathrm{~mm}$ diameter classes, $P_{\text {Elevation }}$ not significant for roots with a diameter of 1-2 mm, Table $2 \mathrm{~b}$ ). The highest fine root biomass of trees was observed in the open forest in all transects (Fig. 2), and it was larger at the tree species line than in the closed forest by $41 \%$ on the Bolshoi Iremel, $79 \%$ on the Mali Iremel, $13 \%$ on the Tchernaya North, and $39 \%$ on the Tchernaya West (Fig. 2). The fine root biomass of shrubs and herbaceous plants in the subplots of the open land was disproportionally higher than that of trees throughout all elevational transects $\left(P_{\text {Vegetation }}<0.001\right.$, Fig. 2). Moreover, it was greater in the Polar Urals than in the South Urals, although this difference appeared not to be significant (Fig. 2, Fig. 1S, Table 2b). The biomass of fine roots of shrubs and herbaceous plants with a diameter of $<1 \mathrm{~mm}$ (and also $<2 \mathrm{~mm}$ ) increased with elevation ( $P_{\text {Elevation }}=0.001$, Fig. 2; Table 2b). The amount of fine root biomass of trees at $0-5 \mathrm{~cm}$ soil depth $\left(43 \pm 6 \mathrm{~g} \mathrm{~m}^{-2}\right.$, $n=36$, average of all elevations and transects $\pm \mathrm{SE}$ ) was greater than at 5-10 cm $\left(27 \pm 3 \mathrm{~g} \mathrm{~m}^{-2}\right)$ and $10-20 \mathrm{~cm}$ $\left(2 \pm 1 \mathrm{~g} \mathrm{~m}^{-2}\right)$. The same pattern was observed for the fine roots of shrubs and herbaceous plants (Fig. 2). Significant negative correlations were found between fine root biomass of trees and several aboveground forest stand parameters as well as the extractable inorganic $\mathrm{N}$ pools in the soil, but no relationships were observed between the fine roots of trees and soil organic C stocks (Table 2a). At the ecosystem level, calculated by considering the crown cover of trees of each altitudinal level, the total living fine root biomass also markedly increased with elevation (Table 3S). The amount of fine root necromass (total mass of dead roots) of the $1-2 \mathrm{~mm}$ in diameter fine roots was higher in the tundra than in the closed forest along all of the studied transects ( $P_{\text {Elevation }}=0.036$, Table $\left.4 \mathrm{~S}\right)$, and the necromass of fine roots with a diameter smaller $1 \mathrm{~mm}$ increased with elevation in the South Urals, but did not show a consistent pattern in the Polar Urals $\left(P_{\text {Region } \times \text { Elevation }}=0.030\right.$, Table $\left.4 \mathrm{~S}\right)$.

Total fine root $\mathrm{N}$ concentrations were significantly higher in the South Urals than in the Polar Urals and were higher in tundra than in closed forest (Table $2 \mathrm{~S}$ ). Total fine root $\delta^{15} \mathrm{~N}$ values were also found to be more positive in the South Urals, but this difference was only marginally significant $\left(P_{\text {Region }}=0.071\right.$, Table $\left.2 \mathrm{~S}\right)$. The $\delta^{15} \mathrm{~N}$ values in fine roots were pronouncedly more negative in the tundra than in the closed forest, both in the subplots of the open land and under tree (Table 2S). This difference was not significant when including all four transects in a linear mixed effect model (Table 2S); however, when considering the two regions separately, the $\delta^{15} \mathrm{~N}$ values in roots were significantly more negative at higher elevations $\left(P_{\text {Elevation }}<0.05\right)$.

\section{Belowground vs aboveground biomass in the forest- tundra ecotone}

Along all four transects, the tree fine root/stem biomass ratio showed a significant exponential increase with elevation (Fig. 3). Considering the amount of biomass stored in both trees and the ground vegetation, the amount of aboveground biomass was larger in the closed forest than at the tree species line by about 17 and 18 times in the South Urals and the Polar Urals, respectively (Fig. 4). Fine and coarse root biomass showed opposite patterns with elevation: while total fine roots (fine roots of trees, shrubs, and herbaceous plant combined) were greater at the tree species line, coarse root biomass was greater in the closed forest. The total amount of root biomass (fine + coarse roots) was seven times smaller at the tree species line than in the closed forest in the South Urals and three times smaller at the tree species line in the Polar Urals (Fig. 4). As a result, the ratio between below- and aboveground biomass decreased from 0.9 at the tree species line to 0.37 in the closed forest of the South Urals and from 2.4 at the tree species line to 0.5 in the closed forest of the Polar Urals.

\section{Root dynamics and extramatrical mycorrhizal mycelia production in the forest-tundra ecotone}

After 1 year of decomposition, mass losses of fine roots were $2.2-18 \%$ greater in the closed forest than at the tree species line for all of the investigated root litter types of different plant growth forms (Fig. 5). The largest effect of elevation on decomposition was observed in the Tchernaya North transect in the Polar Urals. Here, the mass loss of herbaceous roots amounted to $36.8 \pm 1.8 \%$ (mean $\pm \mathrm{SE}$ $n=10$ ) in the closed forest and $18.8 \pm 0.7 \%$ at the tree species line. In each of the four elevational levels, the mass loss of fine roots of trees was significantly lower $(P<0.05)$ than that of shrubs and herbs (including Polygonum spp.).

The rate of EMM production ranged from 0.7 to $24.5 \mathrm{~g} \mathrm{~m}^{-2}$ year $^{-1}$ and did not vary significantly with elevation, although an increase was observed at the transition between the tundra and the open forest (Table 3). The difference between vegetation types was larger in the South Urals with a dense tree canopy of Picea obovata than in the Polar Urals with an open canopy structure under Larix 
Fig. 2 Fine root biomass (diameter $<2 \mathrm{~mm}$ ) of trees under the tree canopy (a-d) and of ground vegetation (shrubs/herbaceous plants) in the open land (e-h) at different soil depths of the Bolshoi Iremel and Mali Iremel transects in the South Urals, and along the Tchernaya North and Tchernaya West transects in the Polar Urals. Data presented as mean $\pm \mathrm{SE}$ $(n=3)$. $T u$ tundra, $S L$ tree species line, $O F$ open forest, $C F$ closed forest along the elevational gradients
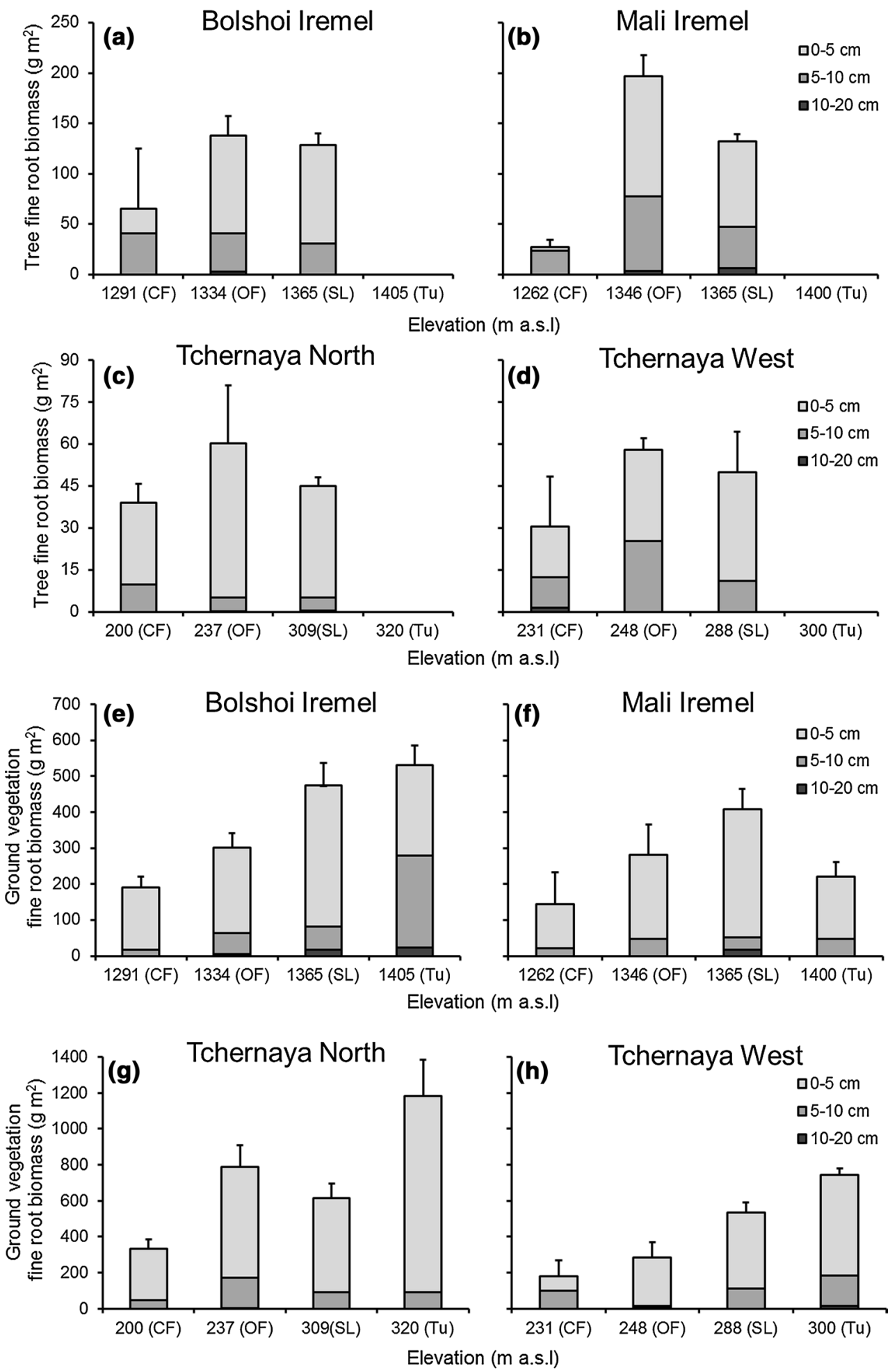

sibirica and a dense ground vegetation under trees $\left(P_{\mathrm{Re}}\right.$ gion $\times$ Vegetation $=0.044$, Table 3 ). The production of EMM was positively correlated to the extractable inorganic $\mathrm{N}$ pool in the South Urals $\left(R^{2}=0.35, P<0.05\right)$, but not in the Polar Urals.
Disentangling climate and vegetation effects on fine root biomass and carbon stocks at the treeline

The path analysis approach confirms the assumption that the total fine root biomass at the treeline ecotone is strongly 
Fig. 3 Dependence of the mean fine root/stem biomass ratio with elevation along the Bolshoi Iremel (circle), Mali Iremel (triangle) transects in the South Urals (a), and the Tchernaya North (square) and Tchernaya West (diamond) transects in the Polar Urals $(\mathbf{b})(n=3)$. $* * * P<0.001$

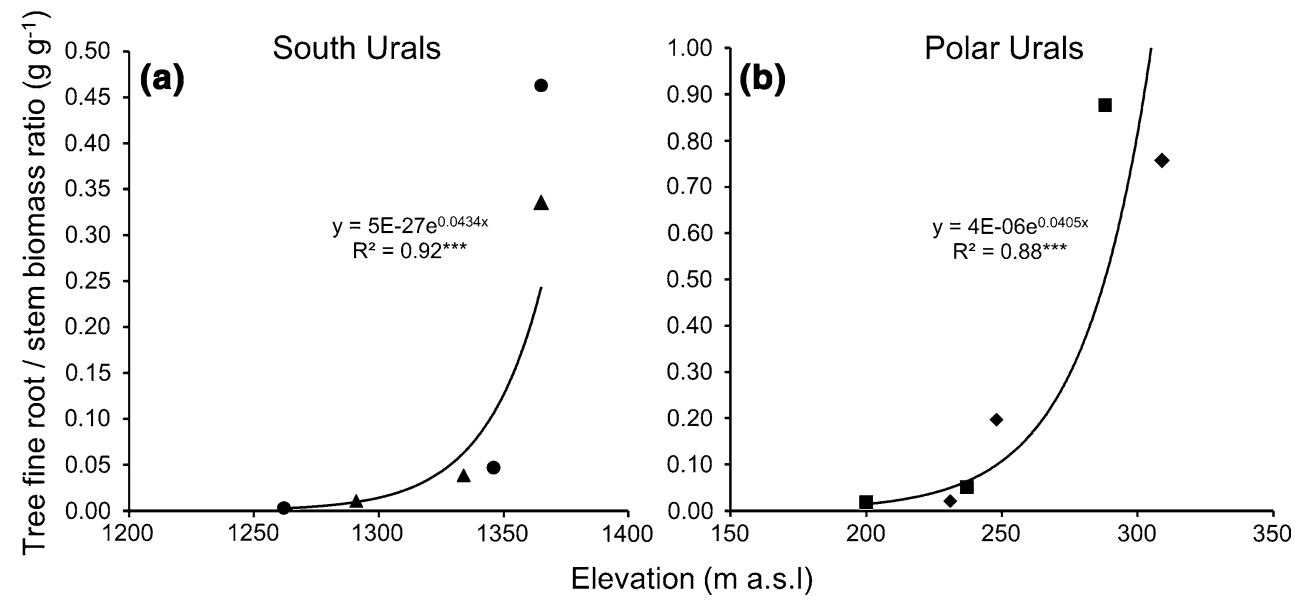

Fig. 4 Comparison between belowground vs aboveground biomass at the tree species line and in the closed forest of South Urals (a) and Polar Urals (b). The aboveground biomass of shrubs represents needles, stems, and twigs. The aboveground biomass of herbaceous plants is represented by their stems

Fig. 5 Fine root litter $(<2 \mathrm{~mm}$ diameter) mass loss (\%) of different plant species at the tree species line and in the closed forest elevational levels along the Mali Iremel transect (South Urals) and the Tchernaya North transect (Polar Urals). Data presented as mean $\pm \mathrm{SE}(n=10)$
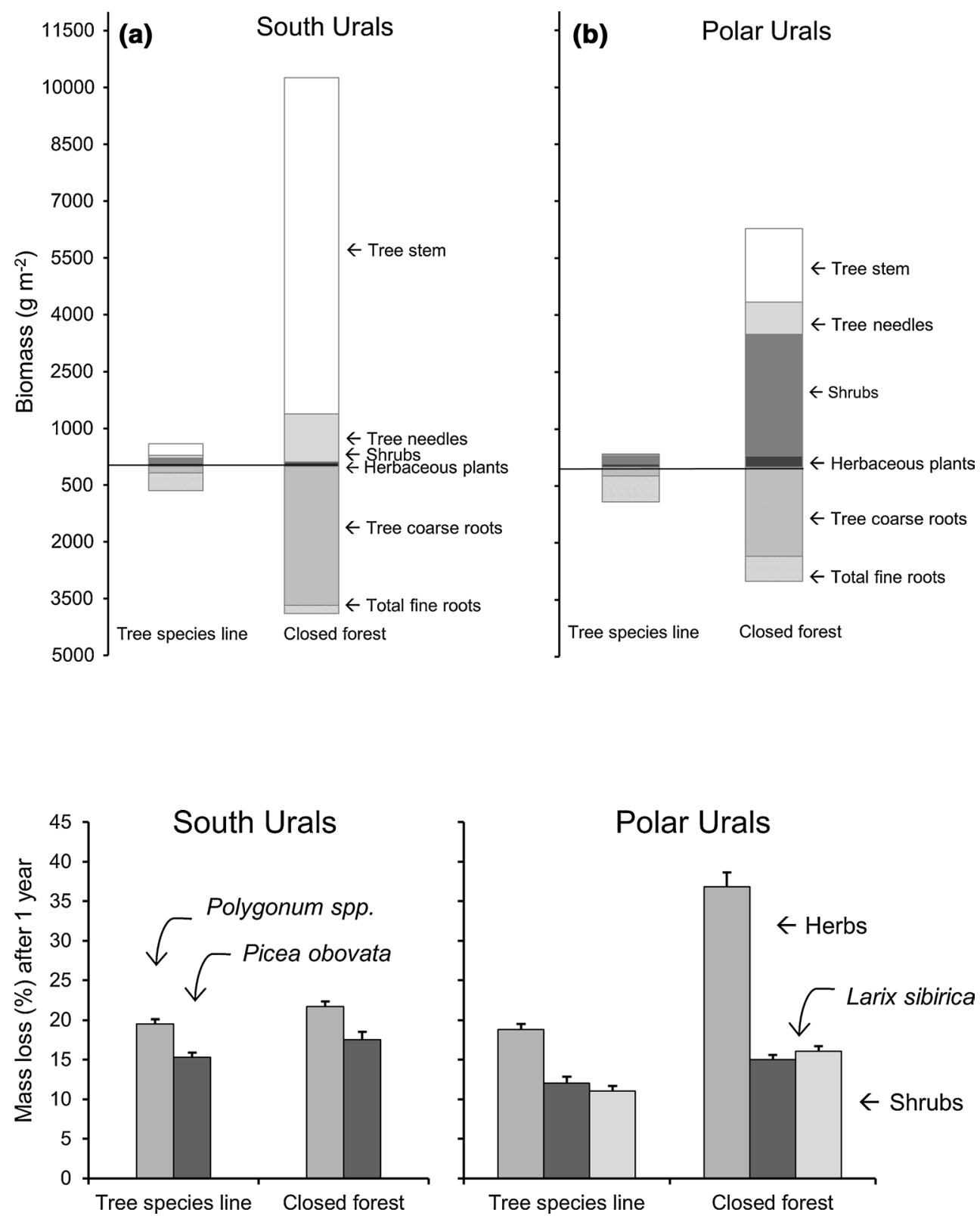
Table 3 Production of extramatrical mycorrhizal mycelia (EMM) production, along the elevational gradients of the South Urals (mean across the Mali Iremel and Bolschoi Iremel transects) and Polar Urals (mean across the Tchernaya North and Tchernaya West transects)

\begin{tabular}{llllllll}
\hline & \multicolumn{1}{l}{ EMM $\left(\mathrm{g} \mathrm{m}^{-2}\right.$ year $\left.^{-1}\right)$} & Fixed effect & Dfn & Dfd & $F$ & $P$ \\
\cline { 2 - 6 } & Open land & Under tree & & & & & \\
\hline South Urals & & & Region & 1 & 2 & 0.493 & 0.555 \\
Tundra & $3.33 \pm 0.93$ & - & Elevation & 1 & 25 & 0.454 & 0.506 \\
Species line & $4.29 \pm 1.14$ & $4.98 \pm 1.21$ & Vegetation & 1 & 25 & 4.434 & $\mathbf{0 . 0 4 5}$ \\
Open forest & $7.75 \pm 1.60$ & $5.10 \pm 1.04$ & Region $\times$ elevation & 1 & 29 & 1.114 & 0.299 \\
Polar Urals & & & Region $\times$ vegetation & 1 & 25 & 4.479 & $\mathbf{0 . 0 4 4}$ \\
Tundra & $5.74 \pm 1.49$ & - & Elevation $\times$ vegetation & 1 & 25 & 3.958 & 0.577 \\
Species line & $9.29 \pm 3.43$ & $6.01 \pm 1.59$ & Region $\times$ elevation $\times$ vegetation & 1 & 25 & 0.253 & 0.619 \\
Open forest & $4.21 \pm 0.77$ & $5.97 \pm 2.01$ & & & & & \\
Closed forest & $5.67 \pm 0.81$ & $5.67 \pm 0.81$ & & & & & \\
\hline
\end{tabular}

Data presented as mean \pm SE for each combination of vegetation type (under tree and open land), elevation, and region $(n=6)$. On the right side of the table, the output of the linear mixed effects models to study the effect of region, elevation, and vegetation on the production of EMM is presented

Numbers in bold represent significant effects $(P<0.05)$

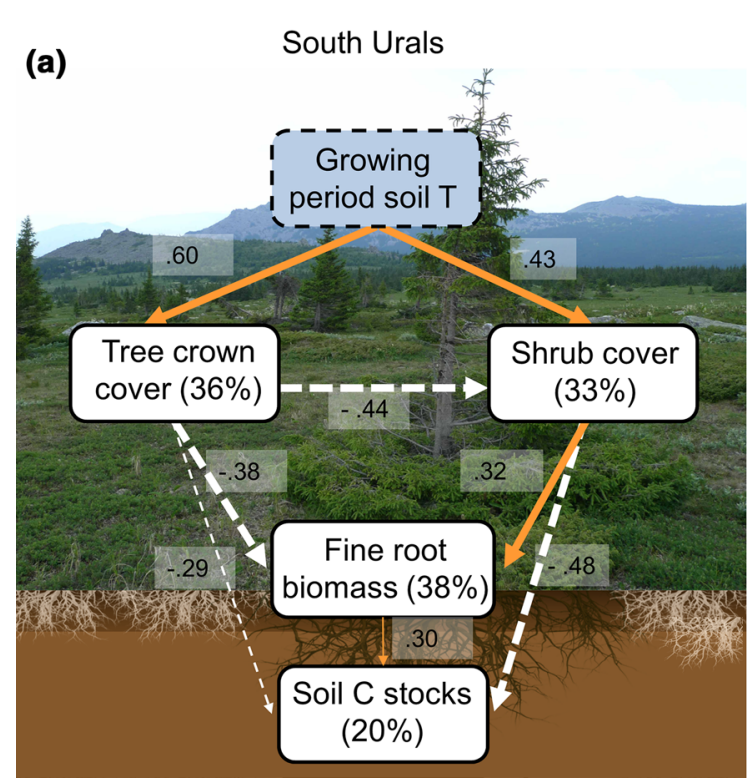

Fig. 6 Path analysis models of (a) soil growing season temperature effects (exogenous variable, light blue rectangle with dotted lines) on vegetation cover, total fine root biomass (of trees, shrubs, and herbaceous plants), and soil organic $\mathrm{C}$ stocks (endogenous variables, white rectangles with solid lines) in the South Urals $\left(n=48, \chi_{2}^{2}=0.565\right.$ $, P=0.754)$ and $(\mathbf{b})$ in the Polar Urals $\left(n=39, \chi_{2}^{2}=3.971\right.$, $P=0.137)$. Numbers on arrows represent standardized path coef-

related to changes in the local tree and shrub cover along the elevational transect and is only indirectly related to climatic conditions (Fig. 6). Including vegetation cover as endogenous variable considerably improved the model performance for both regions. In both regions, the best model of the path analysis also suggested that increases in the growing season temperature significantly increased the tree and shrub cover and that the fine root biomass was positively

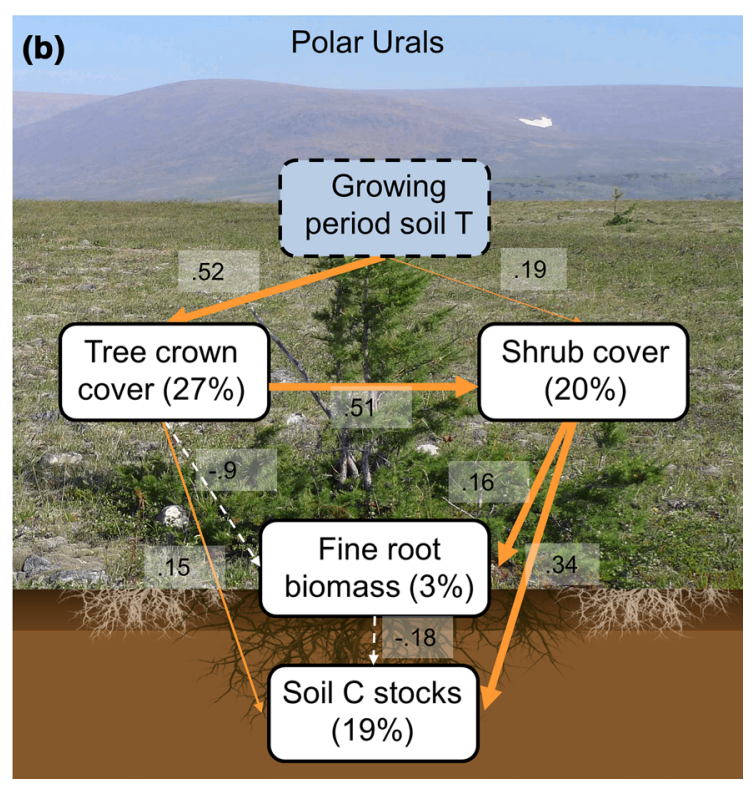

ficients. The thick line arrows represent significant relationships $(P<0.05)$ and the fine line arrows represent not significant relationships. Orange continuous arrows positive relationship, white dotted arrows negative relationship. Percentages indicate the variance explained by the models. Background pictures: Bolshoi Iremel in the South Urals and the Tchernaya North in the Polar Urals. The figure is available in colour in the online version of the journal

influenced by a larger shrub cover. The soil organic C stocks were not found to be influenced by the amount of fine root biomass, although they were significantly related to the shrub cover in both regions (Fig. 6). The $\chi^{2}$ test indicated that our hypothesized path analysis models cannot be rejected as a potential explanation of the observed covariance matrix (South Urals: $n=48, \chi_{2}^{2}=0.565, P=0.754$; Polar Urals: $n=39, \chi_{3}^{2}=3.971, P=0.137$ ). 


\section{Discussion}

Along the Ural Mountain range, forests have advanced into the tundra during the last century, very likely as a result of higher summer temperatures and more snowfall during winter (Fig. 1) (Devi et al. 2008; Hagedorn et al. 2014). Our finding of a 13-79\% greater fine root biomass of trees and an increased ratio between tree fine root/stem biomass with elevation (Figs. 2, 3), from the closed forest to the tree species line, indicate that both in relative and absolute terms, forest upward advances are associated with a decline in fine root biomass of both trees and ground vegetation. This is consistent with the observed elevational increases in fine root biomass of trees and corresponding declines in stem biomass towards the upper limit of trees in boreal, temperate, and tropical zones (Luo et al. 2005; Leuschner et al. 2007; Hertel and Schöling 2011a). Hertel and Schöling (2011a) suggested that the increasing fine root biomass in pure Norway spruce stands towards the upper limit of trees could be related to an unfavourable availability of soil nutrients at higher elevations. Here, we observed a significant negative relationship between the extractable inorganic $\mathrm{N}$ pool in the soil and fine root biomass of trees (Table 2a). This indicates that a larger fine root biomass of trees towards the upper limit of trees could indeed result from a greater mass partitioning into the fine root system to acquire nutrients in the less developed, $\mathrm{N}$-poor soils at higher elevations with a colder climate. This is in agreement with the finding of Dawes et al. (2015), who observed a considerable (ca. 40\%) decline in fine root mass during a 6-year soil warming experiment at an alpine treeline in Switzerland, where warming led to increased inorganic N availability in the soil. In both the South and Polar Urals, also the roots of shrubs and herbaceous plants increased with elevation and, in relative terms, they made up a higher fine root biomass than trees at all elevational levels in both the South and Polar Urals (Fig. 2). This strongly suggests that at higher elevations a greater amount of fine root biomass may be related to a co-occurring competition for nutrients between trees and ground vegetation growing amid trees (i.e. shrubs and herbaceous plants) and the tundra vegetation. The competition might be particularly pronounced in the topsoil where most of the fine root biomass of trees as well as of the ground vegetation is present and most soil inorganic $\mathrm{N}\left(\mathrm{NH}_{4}^{+}+\mathrm{NO}_{3}^{-}\right)$is concentrated (Kammer et al. 2009). Our assumption is supported by studies in forest ecosystems in south-western France and in the subtropics which have already suggested that ground vegetation species cannot be ignored with regard to competition with trees for mineral nutrients and water (Bakker et al. 2006; Fu et al. 2015). Moreover, in the Tibetan Plateau, Liang et al. (2016) indicated that the densification of shrubs just above the upper limit of trees suppressed tree establishment and slowed down the upward movement of forests on a time scale of decades. Overall, these findings indicate that interspecific interactions are major processes controlling the dynamics of treeline ecotones; we suggest that belowground competition is particularly important.

The disproportionately larger fine root biomass of ground vegetation than fine root biomass of trees at each of the investigated elevational levels in all four transects is consistent with the results of an afforestation study on subalpine grasslands (Hiltbrunner et al. 2013), where grasslands had a $40 \%$ higher fine root biomass than spruce stands. Moreover, radiocarbon measurements suggest that fine roots from herbaceous plants turn over more rapidly than those of trees (Solly et al. 2013). In conjunction with the greater biomass in the open land, this may imply a higher root productivity under low stature plants than under trees, which can possibly be attributed to the investment of assimilates in woody structure by trees leaving less $\mathrm{C}$ to be allocated belowground. This indicates the importance of considering the ground vegetation to understand changes in the total variation of fine root biomass along elevational gradients with different forest stand characteristics. In our study, if we account for the expanding canopy cover from the tundra towards the forest, the total fine root biomass clearly decreased by $43 \%$ in the South Urals and $46 \%$ in the Polar Urals.

The path analysis approach supports the idea that root biomass of trees is primarily related to changes in the local tree and shrub cover, and hence in plant functional types along the elevational transects in the Ural Mountains, and only indirectly related to microclimatic conditions. The strong relationship between shrub cover and the total fine root biomass in both regions is likely related to the high amount of fine roots of shrubs and herbaceous plants as compared to tree roots at each elevational level. In Finnish forests, Helmisaari et al. (2007) showed that fine root biomass of the ground vegetation increases with an increasing aboveground cover of shrub cover towards northern latitudes. The dominant influence of ground vegetation on fine root biomass existed despite the opposing relationship of tree cover and shrub cover in the South and Polar Ural (Fig. 6). In the South Urals, the increasing crown cover of Picea obovata with perennial needles towards lower altitudes leads to a suppression of dwarf shrubs (see path analysis; Fig. 6a) and an increasing abundance of tall herbs (i.e. Polygonum spp.) in between tree clusters (Trubina 2006). Instead, in the Polar Urals, shrubs grow and produce the greatest aboveground biomass in the larch forest with a 'light' canopy towards the treeline (Andreyashkina and Peshkova 2005).

Along the elevational transects, the decomposition of fine root litter of trees, shrubs, and herbs was greater in the closed forest than at the tree species line (Fig. 5). This 
is in accordance with the findings of Chen et al. (2008), who observed a faster decomposition of roots at warmer and lower elevation sites, as compared to higher elevation sites in a Douglas-fit old-growth forest. In the Ural Mountains, not only the warmer soil growing season temperatures, but also the observed increases in snow height at lower elevations likely stimulate the activity of the soil microbial decomposer community through higher soil temperatures during winter (Kammer et al. 2009). Hagedorn et al. (2014) recently suggested that forest advances in these regions are primarily related to an increased winter precipitation during the twentieth century, which together with the effect of trees on snow accumulation created more favourable conditions for growth and the establishment of new trees. Our results further show that within one elevation level, the mass loss of fine root litter of trees was smaller than that of herbaceous plants. This is in line with the results of Liu et al. (2016), indicating that changes in decomposition of foliar litter with elevation can be species specific and depend on the chemistry of litter, as well as on the observation that tree roots in temperate forests decompose more slowly than grass roots in temperate grasslands with similar soils and climates (Solly et al. 2014). Taking these findings together suggests that while the closed forest had more favourable microclimatic conditions promoting decomposition, it also had a greater contribution of tree roots with a smaller decomposability. Moreover, an apparently greater fine root biomass in the tundra than in the closed forest (and under the assumption of a similar turnover rate (Sloan et al. 2013), also a greater $\mathrm{C}$ input from roots) might have been 'compensated' by greater inputs from aboveground litter at lower elevations. We, therefore, speculate that changes in root dynamics due to treeline advances will have rather small net effects on total soil $\mathrm{C}$ storage, but soil $\mathrm{C}$ cycling rates might be faster in the closed forest as a result of warmer temperatures in conjunction with a greater input from aboveground biomass (Kammer et al. 2009).

The marked change between total plant below and aboveground biomass with increasing forest cover at lower elevations (Figs. 2, 4) was not paralleled by changes in the production of EMM, except at the transition between the tundra and the occurrence of clusters of trees in the open forest (Table 3). The observed increase of the production of EMM is likely related to an increased proportion of photosynthetically fixed $\mathrm{C}$ allocated to mycorrhizal fungi by ectomycorrhizal trees (Högberg et al. 2001). The increasing production of EMM at the transition between the tundra and the occurrence of trees was likely related to an increasing total host biomass. Moreover, increasing soil temperatures from the tundra towards the closed forest might have influenced EMM production rates indirectly by stimulating $\mathrm{N}$ mineralization at lower elevations
(Kammer et al. 2009), which may stimulate EMM production in $\mathrm{N}$-poor ecosystems (Clemmensen et al. 2006). In agreement with our results, EMM production was found to increase from a heath tundra towards the forest edge in a subarctic treeline ecotone with birch trees in northern Scandinavia (Parker et al. 2015). At the same time, the authors observed the higher rates of $\mathrm{C}$ cycling and the lower soil $\mathrm{C}$ stocks with increasing shrub cover, suggesting that ectomycorrhizal scavenging for nutrients is a mechanism by which organic $\mathrm{C}$ is lost from the soil. The impact of ectomycorrhizal fungi on soil $\mathrm{C}$ storage is, however, controversial (Clemmensen et al. 2013; Ekblad et al. 2013) and in the Ural Mountains there was no obvious linkage between the production of EMM and soil organic C stocks (Kammer et al. 2009; Table 1S). The production of EMM observed in the Ural Mountains was, however, quite low, especially in the Polar Urals, with a magnitude smaller rate as compared to boreal forests quantified with similar methods (Wallander et al. 2011; Table 3). Whether a higher production of EMM with tree establishment into the tundra alters the supply of plants with $\mathrm{N}$ or affects soil organic $\mathrm{C}$ stocks ultimately depends on mycelia turnover and EMM species composition (Ekblad et al. 2013).

\section{Conclusion}

In conclusion, our study along elevational transects in pristine regions of the Ural Mountains indicates that climate change-driven forest expansions into the tundra will lead to a substantial decline in fine root biomass in contrast to aboveground biomass. This decline is primarily attributed to associated changes in the tree and ground vegetation cover and probably also to increases in $\mathrm{N}$ availability. Our results further suggest that warmer temperatures and ameliorated winter conditions at higher elevations will enhance the decomposition of fine root litter, although the magnitude of the responses will differ among plant growth forms. Moreover, the production of EMM is likely to increase with tree establishment into the tundra.

Acknowledgements This work was performed within the framework of the joint projects conceived by the Institute of Plant and Animal Ecology of the Ural Branch of the Russian Academy of Science (IPAE) and the Swiss Federal Institute for Forest, Snow, and Landscape Research (WSL). The project was supported by the following grants: ERA.Net RUS STProject-207, COST Action ES1203 SENFOR (SBFI Nr. C14.0037), RFBR-15-29-02449.

Author contribution statement EFS and FH designed the analysis; EFS analysed the data; EFS and FH wrote the paper; PAM, FH, and SGS conceived the experimental design in the field; ID, PAM, NIA, NMD, VSM, SGS, MRT, MW, and FH conducted fieldwork and provided data; EFS and FHS analysed the fine root biomass; ID and HG analysed the extramatrical mycelia production; all co-authors substantially revised the paper. 


\section{References}

Anadon-Rosell A, Rixen C, Cherubini P, Wipf S, Hagedorn F, Dawes MA (2014) Growth and phenology of three dwarf shrub species in a six-year soil warming experiment at the alpine treeline. PLoS One 9:e100577

Andreyashkina NI, Peshkova NV (2005) Changes in plant cover structure and productivity along an altitudinal gradient (the Polar Urals). Russ J Ecol 36:354-357. doi:10.1007/s11184-005-0084-0

Assessment ACI (2005) Scientific Report. Cambridge University Press. www.acia.uaf.edu/pages/scientific.html. Accessed 22 July 2016

Bahram M, Põlme S, Kõljalg U, Zarre S, Tedersoo L (2012) Regional and local patterns of ectomycorrhizal fungal diversity and community structure along an altitudinal gradient in the Hyrcanian forests of northern Iran. New Phytol 193:465-473. doi:10.1111/j.1469-8137.2011.03927.x

Bai E, Li S, Xu W, Li W, Dai W, Jiang P (2013) A meta-analysis of experimental warming effects on terrestrial nitrogen pools and dynamics. New Phytol 199:441-451

Bakker MR, Augusto L, Achat DL (2006) Fine root distribution of trees and understory in mature stands of maritime pine (Pinus pinaster) on dry and humid sites. Plant Soil 286:37-51. doi:10.1007/s11104-006-9024-4

Berg B (1984) Decomposition of root litter and some factors regulating the process: long-term root litter decomposition in a Scots pine forest. Soil Biol Biochem 16:609-617

Braeker OU (1981) Der Alterstrend bei Jahrringdichten und Jahrringbreiten von Nadelhölzern und sein Ausgleich. Mitteilungen Forstliche Bundes-Versuchsanstalt, Wien 142:75-102

Carvalhais N, Forkel M, Khomik M, Bellarby J, Jung M, Migliavacca M, Mu M, Saatchi S, Santoro M, Thurner M, Weber U, Ahrens B, Beer C, Cescatti A, Randerson JT, Reichstein M (2014) Global covariation of carbon turnover times with climate in terrestrial ecosystems. Nature 514:213-217. doi:10.1038/nature13731

Chapin FS, Shaver GR, Giblin AE, Nadelhoffer KJ, Laundre JA (1995) Responses of arctic tundra to experimental and observed changes in climate. Ecology 76:694-711

Chen H, Rygiewicz P, Johnson M, Harmon M, Tian H, Tang J (2008) Chemistry and long-term decomposition of roots of Douglas-fir grown under elevated atmospheric carbon dioxide and warming conditions. J Environ Qual 37:1327-1336

Clemmensen KE, Michelsen A, Jonasson S, Shaver GR (2006) Increased ectomycorrhizal fungal abundance after long-term fertilization and warming of two arctic tundra ecosystems. New Phytol 171:391-404. doi:10.1111/j.1469-8137.2006.01778.x

Clemmensen K, Bahr A, Ovaskainen O, Dahlberg A, Ekblad A, Wallander H, Stenlid J, Finlay R, Wardle D, Lindahl B (2013) Roots and associated fungi drive long-term carbon sequestration in boreal forest. Science 339:1615-1618

Crawley MJ (2012) The R book. Wiley, Chichester

Cutler DF, Rudall P, Gasson P, Gale R (1987) Root identification manual of trees and shrubs. A guide to the anatomy of roots of trees and shrubs hardy in Britain and Northern Europe. Chapman and Hall, London

Dawes MA, Philipson CD, Fonti P, Bebi P, Hättenschwiler S, Hagedorn F, Rixen C (2015) Soil warming and $\mathrm{CO}_{2}$ enrichment induce biomass shifts in alpine tree line vegetation. Glob Chang Biol 21:2005-2021

Dawes MA, Schleppi P, Hättenschwiler S, Rixen C, Hagedorn F (2016) Soil warming opens the nitrogen cycle at the alpine treeline. Glob Chang Biol doi:10.1111/gcb.13365

Devi N, Hagedorn F, Moiseev P, Bugmann H, Shiyatov S, Mazepa V, Rigling A (2008) Expanding forests and changing growth forms of Siberian larch at the Polar Urals treeline during the 20th century. Glob Chang Biol 14:1581-1591. doi:10.1111/j.1365-2486.2008.01583.x
Ekblad A, Wallander H, Godbold DL, Cruz C, Johnson D, Baldrian P, Björk RG, Epron D, Kieliszewska-Rokicka B, Kjøller R, Kraigher H, Matzner E, Neumann J, Plassard C (2013) The production and turnover of extramatrical mycelium of ectomycorrhizal fungi in forest soils: role in carbon cycling. Plant Soil 366:1-27. doi:10.1007/s11104-013-1630-3

Esper J, Schweingruber FH (2004) Large-scale treeline changes recorded in Siberia. Geophys Res Lett 31:6. doi:10.1029/200 3GL019178

Fu X, Wang J, Di Y, Wang H (2015) Differences in Fine-Root Biomass of Trees and Understory Vegetation among Stand Types in Subtropical Forests. PLoS One 10:e0128894

Gärtner H, Schweingruber FH (2013) Microscopic preparation techniques for plant stem analysis. Verlag Dr Kessel, Remagen, p 78

Gonzalez P, Neilson RP, Lenihan JM, Drapek RJ (2010) Global patterns in the vulnerability of ecosystems to vegetation shifts due to climate change. Glob Ecol Biogeogr 19:755-768. doi:10.1111/j.1466-8238.2010.00558.x

Grace J, Berninger F, Nagy L (2002) Impacts of climate change on the tree line. Ann Bot 90:537-544

Grafius DR, Malanson GP (2015) Biomass distributions in dwarf tree, krummholz, and tundra vegetation in the alpine treeline ecotone. Phys Geogr 36:337-352

Grayston S, Vaughan D, Jones D (1997) Rhizosphere carbon flow in trees, in comparison with annual plants: the importance of root exudation and its impact on microbial activity and nutrient availability. Appl Soil Ecol 5:29-56

Hagedorn F, Shiyatov SG, Mazepa VS, Devi NM, Grigor'ev AA, Bartysh AA, Fomin VV, Kapralov DS, Terent'ev M, Bugman H, Rigling A, Moiseev PA (2014) Treeline advances along the Urals mountain range-driven by improved winter conditions? Glob Chang Biol 20:3530-3543. doi:10.1111/gcb.12613

Handa IT, Hagedorn F, Hättenschwiler S (2008) No stimulation in root production in response to 4 years of in situ $\mathrm{CO} 2$ enrichment at the Swiss treeline. Funct Ecol 22:348-358

Handa IT, Aerts R, Berendse F, Berg MP, Bruder A, Butenschoen O, Chauvet E, Gessner MO, Jabiol J, Makkonen M, McKie BG, Malmqvist B, Peeters ETHM, Scheu S, Schmid B, van Ruijven J, Vos VCA, Hattenschwiler S (2014) Consequences of biodiversity loss for litter decomposition across biomes. Nature 509:218 221. doi:10.1038/nature 13247

Harsch MA, Hulme PE, McGlone MS, Duncan RP (2009) Are treelines advancing? A global meta-analysis of treeline response to climate warming. Ecol Lett 12:1040-1049

Hartley IP, Garnett MH, Sommerkorn M, Hopkins DW, Fletcher BJ, Sloan VL, Phoenix GK, Wookey PA (2012) A potential loss of carbon associated with greater plant growth in the European Arctic. Nat Clim Chang 2:875-879

Helmisaari H-S, Derome J, Nöjd P, Kukkola M (2007) Fine root biomass in relation to site and stand characteristics in Norway spruce and Scots pine stands. Tree Physiol 27:1493-1504

Hertel D, Schöling D (2011a) Below-ground response of Norway spruce to at Mt. Brocken (Germany)_A re-assessment of Central Europe's northernmost treeline. Flora-Morphol Distrib Funct Ecol Plants 206:127-135

Hertel D, Schöling D (2011b) Norway spruce shows contrasting changes in below-versus above-ground carbon partitioning towards the alpine treeline: evidence from a central European case study. Arct Antarct Alp Res 43:46-55

Hiltbrunner D, Zimmermann S, Hagedorn F (2013) Afforestation with Norway spruce on a subalpine pasture alters carbon dynamics but only moderately affects soil carbon storage. Biogeochemistry 115:251-266

Hobbie SE (1992) Effects of plant species on nutrient cycling. Trends Ecol Evol 7:336-339 
Hobbie EA (2006) Carbon allocation to ectomycorrhizal fungi correlates with belowground allocation in culture studies. Ecology 87:563-569

Högberg P, Nordgren A, Buchmann N, Taylor AF, Ekblad A, Högberg MN, Nyberg G, Ottosson-Löfvenius M, Read DJ (2001) Largescale forest girdling shows that current photosynthesis drives soil respiration. Nature 411:789-792

Holmes RL (1995) Dendrochronological program library (computer program). The University of Arizona, Laboratory of Tree Ring Research, Tucson, Arizona

Holtmeier F-K (2009) Mountain timberlines: ecology, patchiness, and dynamics. Springer, Berlin

IPCC (2013) Stocker TF, Qin D, Plattner GK, Tignor M, Allen SK, Boschung J, Nauels A, Xia Y, Bex V, Midgley PM (eds). Climate Change 2013: The Physical Science Basis. Contribution of Working Group I to the Fifth Assessment Report of the Intergovernmental Panel on Climate Change. Cambridge University Press, Cambridge

Iversen CM, Sloan VL, Sullivan PF, Euskirchen ES, McGuire AD, Norby RJ, Walker AP, Warren JM, Wullschleger SD (2015) The unseen iceberg: plant roots in arctic tundra. New Phytol 205:34-58

Kammer A, Hagedorn F, Shevchenko I, Leifeld J, Guggenberger G, Goryacheva T, Rigling A, Moiseev P (2009) Treeline shifts in the Ural mountains affect soil organic matter dynamics. Glob Chang Biol 15:1570-1583. doi:10.1111/j.1365-2486.2009.01856.x

Kernaghan G, Harper K (2001) Community structure of ectomycorrhizal fungi across an alpine/subalpine ecotone. Ecography 24:181-188

Kirdyanov AV, Hagedorn F, Knorre AA, Fedotova EV, Vaganov EA, Naurzbaev MM, Moiseev PA, Rigling A (2012) 20th century tree-line advance and vegetation changes along an altitudinal transect in the Putorana Mountains, northern Siberia. Boreas 41:56-67

Körner C (2003) Alpine plant life, 2nd edn. Springer, Berlin

Körner C (2012) Alpine treelines: functional ecology of the global high elevation tree limits. Springer, Basel

Körner C, Paulsen J (2004) A world-wide study of high altitude treeline temperatures. J Biogeogr 31:713-732

Kullman L (2002) Rapid recent range-margin rise of tree and shrub species in the Swedish Scandes. J Ecol 90:68-77

Leppälammi-Kujansuu J, Ostonen I, Strömgren M, Nilsson LO, Kleja DB, Sah SP, Helmisaari HS (2013) Effects of long-term temperature and nutrient manipulation on Norway spruce fine roots and mycelia production. Plant Soil 366:287-303. doi:10.1007/ s11104-012-1431-0

Leuschner C, Moser G, Bertsch C, Röderstein M, Hertel D (2007) Large altitudinal increase in tree root/shoot ratio in tropical mountain forests of Ecuador. Basic Appl Ecol 8:219-230. doi:10.1016/j.baae.2006.02.004

Liang E, Wang Y, Piao S, Lu X, Camarero JJ, Zhu H, Zhu L, Ellison AM, Ciais P, Peñuelas J (2016) Species interactions slow warming-induced upward shifts of treelines on the Tibetan Plateau. Proc Natl Acad Sci 113:4380-4385. doi:10.1073/ pnas. 1520582113

Liu Y, Chen Y, Zhang J, Yang W, Peng Z, He X, Deng C, He R (2016) Changes in foliar litter decomposition of woody plants with elevation across an alpine forest-tundra ecotone in eastern Tibet Plateau. Plant Ecol 217:495-504. doi:10.1007/ s11258-016-0594-9

Lloyd AH (2005) Ecological histories from Alaskan tree lines provide insight into future change. Ecology 86:1687-1695. doi: $10.2307 / 3450611$

Luo T, Brown S, Pan Y, Shi P, Ouyang H, Yu Z, Zhu H (2005) Root biomass along subtropical to alpine gradients: global implication from Tibetan transect studies. For Ecol Manag 206:349-363
Melillo JM, Butler S, Johnson J, Mohan J, Steudler P, Lux H, Burrows E, Bowles F, Smith R, Scott L (2011) Soil warming, carbon-nitrogen interactions, and forest carbon budgets. Proc Natl Acad Sci 108:9508-9512

Moiseev PA, Shiyatov SG (2003) Vegetation dynamics at the treeline ecotone in the Ural highlands Russia. Alpine biodiversity in Europe. Springer, Berlin, pp 423-435

Moser G, Leuschner C, Hertel D, Graefe S, Soethe N, Iost S (2011) Elevation effects on the carbon budget of tropical mountain forests (S Ecuador): the role of the belowground compartment. Glob Chang Biol 17:2211-2226

Myers-Smith IH, Bruce CF, Martin W, Martin H, Trevor L, Daan B, Ken DT, Marc M-F, Ute S-K, Esther L, Stéphane B, Pascale R, Luise H, Andrew T, Laura Siegwart C, Stef W, Jelte R, Shelly AR, Niels Martin S, Gabriela S-S, Sonja W, Christian R, Cécile BM, Susanna V, Scott G, Laia A-H, Sarah E, Virve R, Jeffrey W, Paul G, Howard EE, David SH (2011) Shrub expansion in tundra ecosystems: dynamics, impacts and research priorities. Environ Res Lett 6:045509

Nylund JE, Wallander H (1992) Ergosterol analysis as a means of quantifying mycorrhizal biomass. In: Norris JR, Read DJ, Varma AK (eds) Methods in microbiology. Academic Press, London, pp $77-88$

Olthof I, Pouliot D (2010) Treeline vegetation composition and change in Canada's western Subarctic from AVHRR and canopy reflectance modeling. Remote Sens Environ 114:805-815. doi:10.1016/j.rse.2009.11.017

Parker TC, Subke J-A, Wookey PA (2015) Rapid carbon turnover beneath shrub and tree vegetation is associated with low soil carbon stocks at a subarctic treeline. Glob Chang Biol 21:2070 2081. doi:10.1111/gcb.12793

Persson H (1980) Spatial distribution of fine-root growth, mortality and decomposition in a young scots pine stand in Central Sweden. Oikos 34:77-87. doi:10.2307/3544552

R Core Team (2014) R: A language and environment for statistical computing. R Foundation for Statistical Computing, Vienna, Austria. http://www.R-project.org/

Rinn F (1998) TSAP V 3.5: computer program for tree-ring analysis and presentation. Frank Rinn Distribution, Germany

Schweingruber F (1978) Mikroskopische Holzanatomie. Anatomie microscopique du bois. Microscopic wood anatomy. Structural variability of stems and twigs in recent and subfossil woods from Central Europe. Zug, Switzerland.: Swiss Fed. Inst. For. Res., Birmensdorf. Edition Zurcherdoi

Simard SW, Jones MD, Durall DM (2003) Carbon and nutrient fluxes within and between mycorrhizal plants. Mycorrhizal ecology. Springer, Berlin, pp 33-74

Sloan VL, Fletcher BJ, Press MC, Williams M, Phoenix GK (2013) Leaf and fine root carbon stocks and turnover are coupled across Arctic ecosystems. Glob Chang Biol 19:3668-3676. doi:10.1111/gcb.12322

Smith SE, Read DJ (1996) Mycorrhizal symbiosis. Cambridge Academic press, Cambridge

Solly E, Schoning I, Boch S, Muller J, Socher S, Trumbore SE, Schrumpf M (2013) Mean age of carbon in fine roots from temperate forests and grasslands with different management. Biogeosciences 10:4833-4843

Solly EF, Schöning I, Boch S, Kandeler E, Marhan S, Michalzik B, Müller J, Zscheischler J, Trumbore SE, Schrumpf M (2014) Factors controlling decomposition rates of fine root litter in temperate forests and grasslands. Plant Soil 382:203-218

Solly E, Schöning I, Herold N, Trumbore S, Schrumpf M (2015) No depth-dependence of fine root litter decomposition in temperate beech forest soils. Plant Soil 393:273-282. doi:10.1007/ s11104-015-2492-7 
Stow DA, Hope A, McGuire D, Verbyla D, Gamon J, Huemmrich F, Houston S, Racine C, Sturm M, Tape K, Hinzman L, Yoshikawa K, Tweedie C, Noyle B, Silapaswan C, Douglas D, Griffith B, Jia G, Epstein H, Walker D, Daeschner S, Petersen A, Zhou L, Myneni R (2004) Remote sensing of vegetation and land-cover change in Arctic Tundra Ecosystems. Remote Sens Environ 89:281-308. doi:10.1016/j.rse.2003.10.018

Sturm M, Racine C, Tape K (2001) Climate change: increasing shrub abundance in the Arctic. Nature 411:546-547

Tamminen P, Starr M (1994) Bulk density of forested mineral soils. Silva Fennica 28:53-60

Trubina MR (2006) Distribution of plants differing in attitude toward thermal conditions in communities of the timberline ecotone on Mount Iremel', the Southern Urals. Russ J Ecol 37:306-315. doi:10.1134/S1067413606050031
Wallander H (2006) External mycorrhizal mycelia-the importance of quantification in natural ecosystems. New Phytol 171:240-242. doi:10.1111/j.1469-8137.2006.01803.x

Wallander H, Nilsson LO, Hagerberg D, Bååth E (2001) Estimation of the biomass and seasonal growth of external mycelium of ectomycorrhizal fungi in the field. New Phytol 151(3):753-760

Wallander H, Ekblad A, Bergh J (2011) Growth and carbon sequestration by ectomycorrhizal fungi in intensively fertilized Norway spruce forests. For Ecol Manag 262:999-1007. doi:10.1016/j. foreco.2011.05.035

Zhu Y-G, Miller RM (2003) Carbon cycling by arbuscular mycorrhizal fungi in soil-plant systems. Trends Plant Sci 8:407-409 